\title{
Trends of Area, Production and Productivity of Linseed in Different Districts of Chhattisgarh, India
}

\author{
D.R. Agashe*, A.S.R.A.S. Sastri, Pandurang Bobade and Rajni Agashe \\ Department of Agro meteorology, Indira Gandhi Krishi Vishwa Vidalaya Raipur C.G., India \\ *Corresponding author
}

A B S T R A C T

\begin{tabular}{|l|}
\hline Key word s \\
Area, Production \\
and Productivity, \\
Linseed
\end{tabular}

Time trend analysis of area of linseed shows that the area is decreasing at an alarming rate in all the major linseed growing districts including Raipur (@1812/yr; $\left.\mathrm{R}=0.85^{* *}\right)$, Rajnandgaon (@849/yr; $\mathrm{R}=0.72 * *$ ), Bilaspur (@824/yr; $\mathrm{R}=0.78 * *$ ), and Durg (@348/yr; R = 0.32), however decreasing area in Durg is not statistically significant. The reason being that in Chhattisgarh linseed crop is cultivated under utera cultivation under rice based rainfed cropping. The area in Raigarh $\left(\mathrm{R}=0.87^{* *}\right)$ and Surguja $(\mathrm{R}=0.83 * *)$ districts is increasing but these districts are not important as far as linseed area is concerned. The under Bastar district showed no sign of change. The production of linseed positively increased in Raigarh ( $\mathrm{R}=0.80 * *)$, Bastar $\left(\mathrm{R}=0.52^{* *}\right)$ and Surguja $(\mathrm{R}=0.44 *)$ districts due to increased area in these districts. Whereas, there is decreasing trend in Raipur $\left(\mathrm{R}=0.38^{*}\right)$ and Bilaspur $(\mathrm{R}=0.05)$. The districts of Durg $(\mathrm{R}=0.27)$ and Rajnandgaon $(R=0.14)$ also show increasing production trend, which is non-significant. The productivity of linseed is significantly increasing in all districts due to introduction of high yielding varieties and agricultural mechanization in recent years.

\section{Introduction}

India ranks third in the world in respect to area and production of linseed. Linseed is the principal oilseed crop grown in Chhattisgarh under utera in rainfed conditions. It occupies $34 \%$ share in total oilseeds production in the state and $17 \%$ in India. The total area of linseed is 162 thousand ha, production is 74.7 thousand tonnes and productivity is $288 \mathrm{~kg}$ ha${ }^{1}$ (Hegde, 2005). Despite the premier position, the country holds in the production of oilseed, the productivity level has remained virtually static in the last couple of year with no major breakthrough in achieving productivity enhancement and yield stabilization. This is mainly due to cultivation of oilseed crops under rain-fed condition $(76 \%)$ and the vulnerability of the released cultivars to an array of stresses, both biotic and abiotic in nature.

\section{Materials and Methods}

The present study is carried out in the state Chhattisgarh, which came in to existence on 
$1^{\text {st }}$ Nov. 2000 as a result of bifurcation of M.P. state. It lies in eastern part of India and located between $17^{\circ} 41^{\prime} \mathrm{N}$ and $24^{\circ} 45^{\prime} \mathrm{N}$ latitude and $79^{\circ} 30^{\prime} \mathrm{E}$ and $84^{\circ} 15^{\prime} \mathrm{E}$ longitude. Orrisa surrounds it in the east in the west by M.P. and
Maharashtra, in the north by U.P. and Jarkhand and in the south by Andhra Pradesh.

The study was carried out in 7 undivided districts of Chhattisgarh regions, which are:

Table.1

\begin{tabular}{clll}
\hline S.No & Station & Latitude & Longitude \\
\hline 1 & Raipur & $21^{\circ} 14^{\prime} \mathrm{N}$ & $81^{\circ} 39^{\prime} \mathrm{E}$ \\
2 & Durg & $21^{\circ} 13^{\prime} \mathrm{N}$ & $81^{\circ} 17^{\prime} \mathrm{E}$ \\
3 & Rajnandgaon & $21^{\circ} 05^{\prime} \mathrm{N}$ & $81^{\circ} 02^{\prime} \mathrm{E}$ \\
4 & Bastar & $19^{\circ} 05^{\prime} \mathrm{N}$ & $82^{\circ} 02^{\prime} \mathrm{E}$ \\
5 & Bilaspur & $22^{\circ} 05^{\prime} \mathrm{N}$ & $82^{\circ} 08^{\prime} \mathrm{E}$ \\
6 & Raigarh & $21^{\circ} 55^{\prime} \mathrm{N}$ & $83^{\circ} 24^{\prime} \mathrm{E}$ \\
7 & Surguja & $23^{\circ} 07^{\prime} \mathrm{N}$ & $83^{\circ} 12^{\prime} \mathrm{E}$ \\
\hline
\end{tabular}

The long term crop data in regard to area, production and productivity for groundnut sesames, linseed, rapeseed-mustard, soybean and total oilseeds that are grown during kharif and rabi seasons of different districts of Chhattisgarh were collected from the published records of department of Agriculture, Government of Madhya Pradesh, Bhopal and Government of Chhattisgarh, Raipur. Data were obtained for the period 1974-75 to 2003-04 and were used in present study.

\section{Trend analysis}

For temporal analysis of area, production and productivity of oilseeds crop in undivided districts of Chhattisgarh the time trend equations were constructed as:

$$
\begin{aligned}
& \mathrm{Y}=\mathrm{a}+\mathrm{b} \mathrm{X} \\
& \text { Where, } \\
& \mathrm{Y}=\text { area, production, productivity } \\
& \mathrm{X}=\text { year } \\
& \mathrm{a}=\text { intercept } \\
& \mathrm{b}=\text { slope }
\end{aligned}
$$

The slope indicates the trend of area, production and productivity over the study period.

\section{Results and Discussion}

\section{Area}

The time trend pattern of the area of linseed in Raipur is depicted in Figure 1.1, which, shows that area is gradually decreasing. The largest area was observed in the year 1978-79 (73.4 thousand ha) and the lowest area was found in the year 2002-03 (11.3 thousand ha). The regression equation is $\mathrm{Y}=-1.8214 \mathrm{X}+61.265$ and $\mathrm{R}$ value is 0.85 , which is highly significant at $1 \%$ probability level.

In Durg district, area of linseed largely fluctuated during the study period with decreasing trend as shown in Figure 1.1. The highest area was observed in the year 1978-79 (59.9 thousand ha) and the lowest area was observed in the year 1989- 90 (24.1 thousand ha). The time trend regression equation is $\mathrm{Y}=$ $-0.3483 \mathrm{X}+47.322$ and $\mathrm{R}$ value is 0.32 , which is non- significant.

In Rajnandgaon district, the area of linseed decreased gradually as shown in Fig. 1.1. The 
highest area of 74.0 and the lowest area of 22.5 were observed in the years 1975-76 and 2002-03, respectively. The trend of regression equation is $\mathrm{Y}=-0.8493 \mathrm{X}+62.217$ and $\mathrm{R}$ value is 0.72 , which is statistically highly significant at $1 \%$ probability level.

The time trend pattern of area of linseed for different years in Bastar district is shown in Fig. 1.1. Figure shows high interannual variability. The highest area was observed in the year 2001-02 (10.8 thousand ha.) and the lowest area was found in the year 1992-93 (2.8 thousand ha). The regression equation is $\mathrm{Y}=0.0343 \mathrm{X}+4.212$ and $\mathrm{R}$ value is 0.16 , which is non- significant.

Linseed crop in Bilaspur district was introduced in 1985-86 and since then the area is continuously decreasing as shown in Fig. 1.1. The highest area was observed in the year 1985-86 (33.3 thousand ha) and lowest area was observed in the year 2002-03 (7.7 thousand ha). The time trend equation is $\mathrm{Y}=$ $0.8242 \mathrm{X}+27.389$ and $\mathrm{R}$ value is 0.78 , which is significant at $1 \%$ probability level.

In Raigarh district, the area under linseed in increases slowly (41 ha/ year ${ }^{-1}$ ) but constantly as shown in Fig. 1.1. The highest area was found in the year 2002- 03 (2.1 thousand ha) and the lowest area was found in the year 1974-75 (0.5 thousand ha). The regression equation is $\mathrm{Y}=0.0412 \mathrm{X}+0.4487$ and $\mathrm{R}$ value is 0.87 , which is highly significant at $1 \%$ probability level.

In Surguja district, the area of linseed has increased considerably during the study period as shown in Figure 1.1. The highest area was found in the year 2003-04 (15.0 thousand ha) and the lowest area was found in the year 1976-77 (3.1 thousand ha). The regression equation is $\mathrm{Y}=0.3193 \mathrm{X}+2.731$ and $\mathrm{R}$ value is 0.83 , which is highly significant at $1 \%$ probability level.
Time trend analysis of area of linseed shows that the area is decreasing at an alarming rate in all the major linseed growing districts including Raipur (@1812/yr; $\mathrm{R}=0.85^{* *}$ ), Rajnandgaon (@849/yr; R = 0.72**), Bilaspur (@824/yr; R=0.78**), and Durg (@348/yr; R $=0.32$ ), however decreasing area in Durg is not statistically significant. The reason being that in Chhattisgarh linseed crop is cultivated under utera cultivation under rice based rainfed cropping. The area in Raigarh $(\mathrm{R}=$ $0.87 * *)$ and Surguja ( $\left.\mathrm{R}=0.83^{* *}\right)$ districts is increasing but these districts are not important as far as linseed area is concerned. The under Bastar district showed no sign of change.

\section{Production}

In Raipur, linseed production witnessed high degree of fluctuations with overall negative trend as shown in Figure 1.2. The highest production was found in the year 1975-76 (9.1 thousand tonnes) and the lowest the production was found in the year 1995-96 (1.1 thousand tonnes). The time trend equation is $\mathrm{Y}$ $=-0.0895 X+5.1372$ and $R$ value 0.38 , which is significant at $5 \%$ probability level.

The production pattern of linseed in Durg for different years has been depicted in Figure 1.2. A large year-to-year variation has been observed in linseed yield during study period. The highest production was found in the year 2002-03 (16.3 thousand tonnes), whereas, lowest production was found in the year 197980 (2.1 thousand tonnes). The regression equation is $\mathrm{Y}=0.107 \mathrm{X}+6.088$ and $\mathrm{R}$ value is 0.27 , which is non-significant.

The production of linseed has highly fluctuated in Rajnandgaon as shown in Figure 1.2. The highest production was found in the year 1975-76 (15.6 thousand tonnes) and the lowest in the year 1979-80 (2.0 thousand tonnes). The regression equation is $\mathrm{Y}=0.0544$ $\mathrm{X}+8.4166$ and $\mathrm{R}$ value is 0.14 , which is non- 
significant.

In Bastar district, the production of linseed stagnated in the different years as shown in Figure 1.2. The highest production was found in the year 2001-02 (3.7 thousand tonnes), whereas, lowest production was found in the year 1976-77 (0.5 thousand tonnes). The regression equation is $\mathrm{Y}=0.0399 \mathrm{X}+0.4954$ and $R$ value is 0.52 , which is significant at 1 $\%$ probability level.

The production of linseed in Bilaspur followed large-scale interannual variations as shown in Figure 1.2. The highest production was observed in the year 2003-04 (10.8 tonnes) and the lowest production was observed in the year from 1997-89. The regression equation is $\mathrm{Y}=-0.0158 \mathrm{X}+4.4947$ and $\mathrm{R}$ value is 0.05 , which is non-significant.

The production pattern of linseed in Raigarh district observed slow but steady growth as shown in Figure 1.2. The highest production was found in the year 2003-04 (0.6 thousand tonnes), whereas, lowest production was found in the year 1976-77 (0.05 thousand tonnes). The regression equation is $\mathrm{Y}=0.0123$ $\mathrm{X}+0.053$ and $\mathrm{R}$ value is 0.80 , which is highly significant at $1 \%$ probability level.

The linseed production in Surguja district observed large year-to-year variations with overall positive growth of 0.79 tonnes per year as shown in Figure 1.2. The highest production was found in the year 1981-82 (6.7 thousand tonnes) and the lowest production was found in the year 1979-80 (0.2 thousand tonnes). The time trend regression equation is $\mathrm{Y}=0.0872 \mathrm{X}+0.209$ and $\mathrm{R}$ value is 0.79 , which was highly significant at $1 \%$ probability level.

The production of linseed positively increased in Raigarh $\left(\mathrm{R}=0.80^{* *}\right)$, Bastar $\left(\mathrm{R}=0.52^{* *}\right)$ and Surguja $(\mathrm{R}=0.44 *)$ districts due to increased area in these districts. Whereas, there is decreasing trend in Raipur $\left(\mathrm{R}=0.38^{*}\right)$ and Bilaspur $(\mathrm{R}=0.05)$. The districts of Durg $(\mathrm{R}=0.27)$ and Rajnandgaon $(\mathrm{R}=0.14)$.

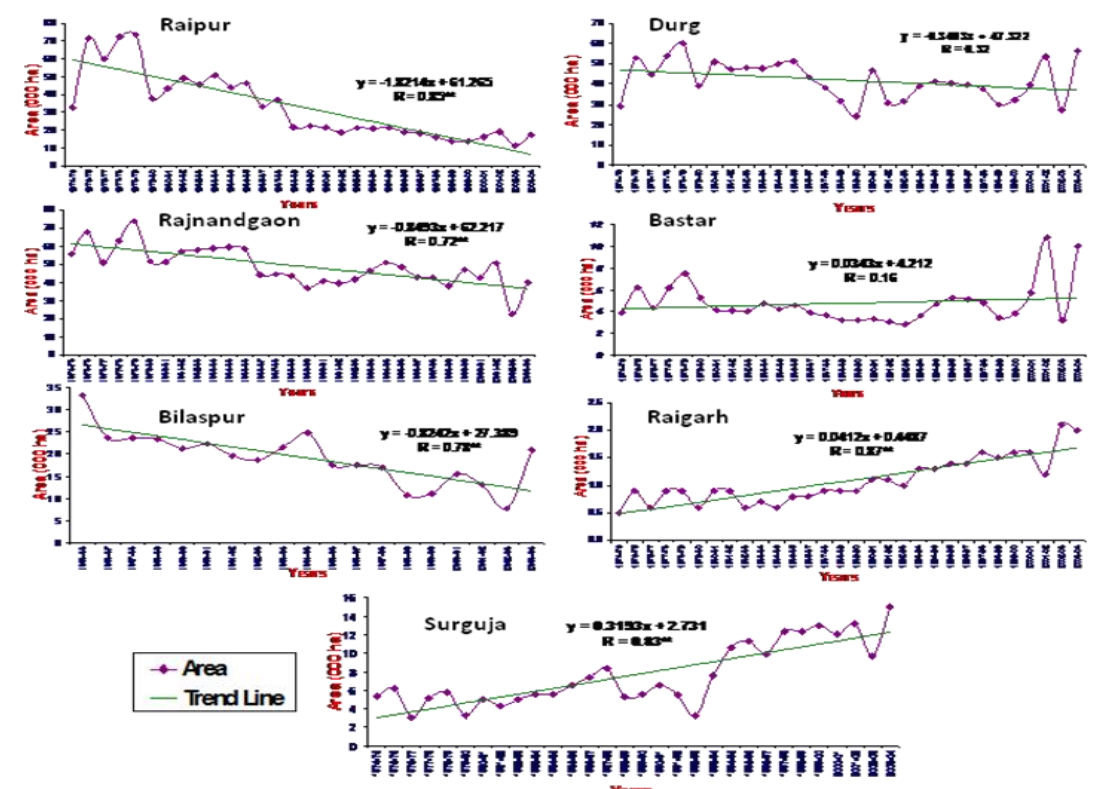

Fig. 1.1 : Trends of area of linseed in different districts of Chhattisgarh 

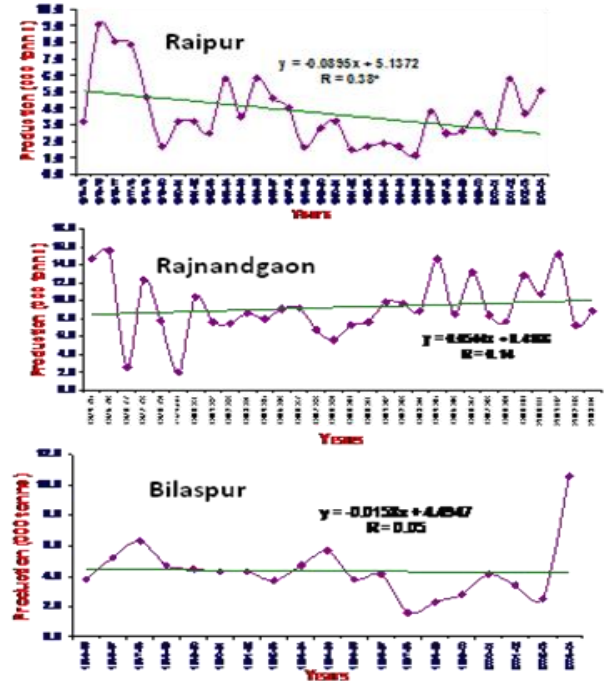
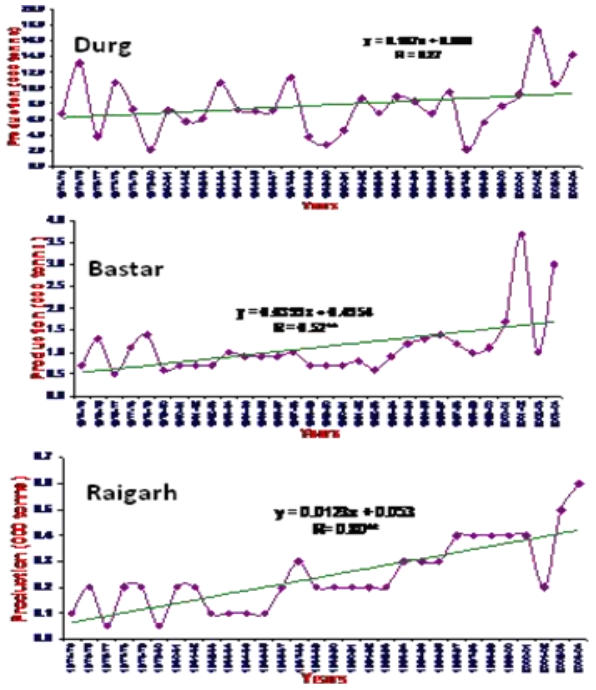

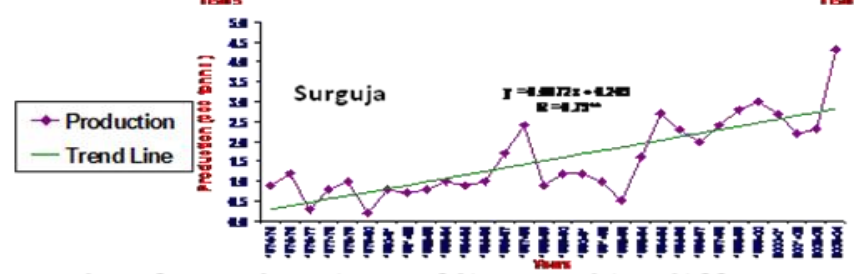

Fig. 1.2 : Trends of production of linseed in different districts of Chhattisgarh
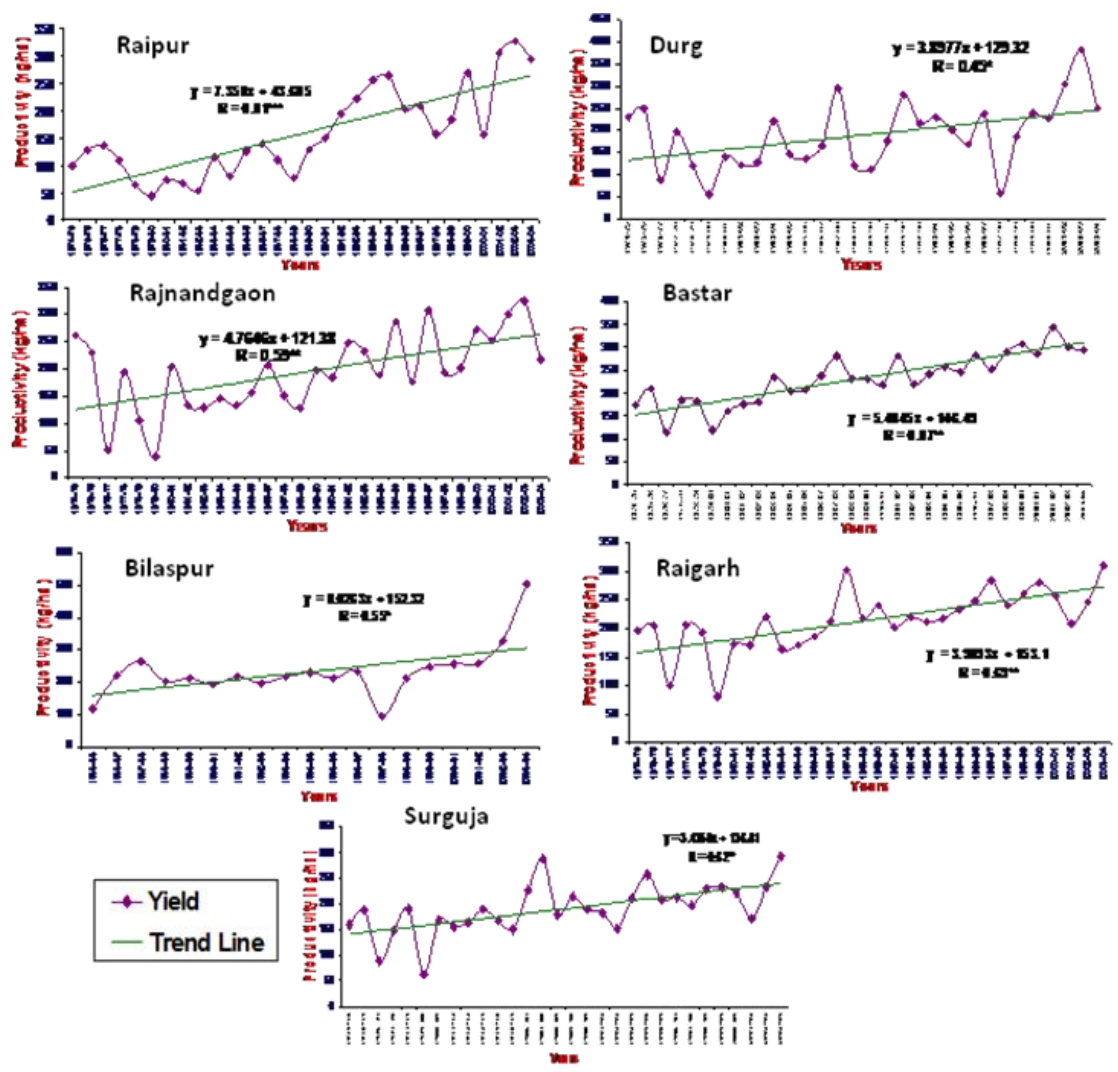

Fig. 1.3 : Trends of productivity of linseed in different districts of Chhattisgarh 


\section{Productivity}

In Raipur district, the linseed productivity increases (Fig. 1.3) at the rate of 7.4 $\mathrm{kg} / \mathrm{ha} /$ year. The highest productivity was found in the year 2002-03 $\left(326 \mathrm{~kg} \mathrm{ha}^{-1}\right)$ and the lowest yield was found in the year 1979$80\left(64 \mathrm{~kg} \mathrm{ha}^{-1}\right)$. The regression equation is $\mathrm{Y}$ $=7.358 \mathrm{X}+43.685$ and $\mathrm{R}$ value is 0.81 , which is highly significant at $1 \%$ probability level.

The trend of productivity of linseed showed, fluctuations in Durg district in different years as shown in Figure 1.3. The highest productivity of $384 \mathrm{~kg} \mathrm{ha}^{-1}$ and the lowest productivity of $58 \mathrm{~kg} \mathrm{ha}^{-1}$ were observed in the years 2002-03 and 1997-98, respectively. The time trend equation is $\mathrm{Y}=3.8977 \mathrm{X}$ +129.32 and $R$ value is 0.45 , which is significant at $5 \%$ probability level.

The trend of productivity of linseed in Rajnandgaon district has been depicted in Figure 1.3, which showed overall positive growth of $4.8 \mathrm{~kg} / \mathrm{ha} /$ year. The highest productivity was found in the year 2002-03 (324 kg ha ${ }^{-1}$ ), whereas, lowest productivity was found in the year 1979-80 $\left(40 \mathrm{~kg} \mathrm{ha}^{-1}\right)$. The regression equation is $\mathrm{Y}=4.7646 \mathrm{X}$ +12.38 and $\mathrm{R}$ value is 0.59 , which is highly significant at $1 \%$ probability level.

In Bastar district, the productivity of linseed consistently increased as shown in Figure 1.3. The highest productivity of $343 \mathrm{~kg} \mathrm{ha}^{-1}$ and the lowest productivity of $114 \mathrm{~kg} \mathrm{ha}^{-1}$ were observed in the years 2001-02 and 1976-77. The time trend regression equation is $\mathrm{Y}=$ $5.4845 \mathrm{X}+146.49$ and $\mathrm{R}$ value is 0.87 , which is highly significant at $1 \%$ probability level.

The productivity of linseed in Bilaspur district also increased as shown in Figure 1.3. The highest productivity was found year 2003-04 $\left(516 \mathrm{~kg} \mathrm{ha}^{-1}\right)$ and the lowest productivity (93 $\left.\mathrm{kg} \mathrm{ha}^{-1}\right)$ was found in the year 1997-98 $(94 \mathrm{~kg}$ $\left.\mathrm{ha}^{-1}\right)$. The time trend regression equation is $\mathrm{Y}$ $=8.0263 \mathrm{X}+152.32$ and $\mathrm{R}$ value is 0.55 , which is significant at $1 \%$ probability level.

In Raigarh district, the productivity of linseed increased consistently as shown in Figure 1.3. The highest productivity was found in the year 2003-04 (309 $\left.\mathrm{kg} \mathrm{ha}^{-1}\right)$ and the lowest productivity was found in the year 1979-80 $\left(81 \mathrm{~kg} \mathrm{ha}^{-1}\right)$. The time trend regression equation is $\mathrm{Y}=3.9893 \mathrm{X}+153.1$ and $\mathrm{R}$ value is 0.69 , which is significant at $1 \%$ probability level.

In Surguja district, the time trend of productivity of linseed observed positive growth of $3.4 \mathrm{~kg} / \mathrm{ha} /$ year as shown in Figure 1.3. The highest productivity of $292 \mathrm{~kg} \mathrm{ha}^{-1}$ and the lowest productivity of $61 \mathrm{~kg} \mathrm{ha}^{-1}$ were found in the years 2003-04 and 1979-80, respectively. The regression equation is $\mathrm{Y}=$ $3.4358 \mathrm{X}+136.81$ and $\mathrm{R}$ value is 0.62 , which is significant at $1 \%$ probability level.

The productivity of linseed is significantly increasing in Raipur ( $\left.\mathrm{R}=0.81^{* *}\right)$, Durg $(\mathrm{R}=$ $\left.0.45^{*}\right)$, Rajnandgaon $\left(\mathrm{R}=0.59^{* *}\right)$, Bastar $(\mathrm{R}$ $\left.=0.87^{* *}\right)$, Bilaspur $\left(\mathrm{R}=0.55^{* *}\right)$, Raigarh $(\mathrm{R}$ $\left.=0.69^{* *}\right)$ and Surguja $\left(\mathrm{R}=0.62^{* *}\right)$ districts due to introduction of high yielding varieties and agricultural mechanization in recent years.

Sodhiya (1990) estimated the linear trend in area, production and productivity of 10 major crops in Sagar division, Madhya Pradesh, for the period 1956-57 to $1982-83$. He covered various crops such as wheat, rice, sorghum, millet, barley (in the cereal group), chickpea, lentil (pulse group) and linseed, sesamum, and soybean (in the oilseed crop). He found that crop such as sorghum and millet is decreasing, while, the production was increasing of some inferior crop like sesamum. 


\section{References}

Hegde, D.M. 2005. Oilseed Scenario - Past, Present and Future with special reference to rapeseed-mustard. In: Winter school held at National center for Rapeseed-Mustard, Sewar, Bhartpur, Rajasthan. pp. 1.
Gauraha, A.K., Shrivastava, R.S.L., Banafar, K.N.S. and Mathur, P. 2003. Production performance resource use efficiency, technology adoption and constraints in chickpea production in Durg district of Chhattisgarh International Chickpea Conference, Raipur, C.G., India, pp. 104-109.

\section{How to cite this article:}

Agashe, D.R., A.S.R.A.S. Sastri, Pandurang Bobade and Rajni Agashe. 2018. Trends of Area, Production and Productivity of Linseed in Different Districts of Chhattisgarh, India. Int.J.Curr.Microbiol.App.Sci. 7(07): 711-718. doi: https://doi.org/10.20546/ijcmas.2018.707.085 